\title{
EKSEGESIS KOTBAH: \\ Petunjuk Praktis Bagi Pelaksanaan Firman Tuhan
}

\author{
Susanto Dwiraharjo, ${ }^{1}$ Susanti Embong Bulan ${ }^{2}$ \\ Sekolah Tinggi Teologi Baptis, Jakarta \\ Sekolah Tinggi Teologi Widya Agape, Nunukan \\ Email: gitagracia_9903@yahoo.co.id
}

Submited: 11 January 2021 Revision: 27 April 2021 Published: 28 May 2021

\begin{abstract}
Background, delivery of God's Word or sermon is an integral part of Christian ministry. In fact, there are various patterns and methods of interpretation when preparing a sermon. This is often a problem for a preacher. The method used in this research is the hermeneutic method. This is an attempt to find the actual truth of the excavated text. The output of this research is expected to contribute ideas and also practical instructions for the implementation of the ministry of God's Word. The conclusion of all this is that the exegesis of this sermon can be a direction for every servant of God in preparing his sermon.
\end{abstract}

Keywords: exegese, preach, god's word

\begin{abstract}
Abstrak
Latar belakang, penyampaian Firman Tuhan atau kotbah merupakan bagian yang menyatu dengan pelayanan Kekristenan. Pada faktanya terdapat berbagai pola dan metode tafsir ketika sedang mempersiapkan kotbah. Hal itu sering menjadi persoalan sendiri bagi seorang pengkotbah. Metode yang digunakan dalam penelitian ini adalah metode hermeneutik. Ini merupakan upaya untuk menemukan kebenaran yang sebenarnya dari teks yang digali. Luaran penelitian ini diharapkan dapat memberi sumbangsih pemikiran dan juga petunjuk praktis bagi pelaksanaan pelayanan Firman Tuhan. Kesimpulan dari semuanya ini adalah agar eksegesis kotbah ini dapat menjadi arahan bagi setiap hamba Tuhan dalam mempersiapkan kotbahnya.
\end{abstract}

Kata kunci: eksegese, kotbah, firman tuhan

\section{PENDAHULUAN}

Kata exegesis diambil dari istilah Yunani exegomai yang digunakan untuk pelajaran Alkitab. Arti dasarnya adalah "memimpin keluar/ membawa keluar." Ini berarti penafsirannya dikeluarkan atau didapat dari teks. Lawan katanya adalah eisegesis, yang berarti "memimpin kedalam," atau membawa pemikiran dari luar ke dalam teks. ${ }^{1}$ Di dalam Septuaginta, kata "exegomai" diterjemahkan dari bahasa Ibrani "rps -sapar," yang berarti

${ }^{1}$ Musajon Tadjibayev. "Understanding a Deep Essence of a Literary Work without Comments." European Journal of Research and Reflection in Educational Sciences, 8, no.5 (2020), Part II: 26-31.

https://www.idpublications.org/wpcontent/uploads/2020/05/Full-PaperUNDERSTANDING-A-DEEP-ESSENCE-OF-ALITERARY-WORK-WITHOUT-COMMENTS.pdf; Allen Ros. www. bible org. 
"menceritakan, mengatakan, atau mendeklarasikan."2 Kata kerja ini ditemukan hanya di dalam Perjanjian Baru (Luk.24:35; Yoh.1:18 dan Kis.10:8; 15:12; 21:19), dan diterjemahkan "menceritakan, mempertalikan, menghubungkan," dan juga dapat didefinisikan "menerangkan."3 Dengan demikian ketika dikaitkan dengan studi tentang Alkitab, maka kata eksegesis dapat diartikan "untuk menerangkan kata, kalimat, paragraf, atau keseluruhan buku dengan membawa keluar kebenaran dan arti asli teks yang ada di dalamnya. Ini merupakan langkah terbaik untuk kembali menemukan arti dari sumber asli di dalam dokumen yant tertulis. ${ }^{4}$ Pengertian ini tidak cukup hanya dipahami dalam ranah kognitif, namun perlu dipraktekan.

Praktek eksegesis seringkali hanya digunakan dalam perkuliahan. Banyak hamba Tuhan yang dididik di sekolah teologi memiliki pengalaman membuat makalah eksegesis, tetapi hanya sedikit yang diajarkan bagaiamana membuat peralihan dari pekerjaan dan keahlian

2 Walter C. Kaiser, JR. Toward an Exegetical Theology, biblical Exegesis for Preaching and teaching. (Grand Rapids: Baker Book House, 1988), 43-44.

3 John Grassmick. Principles and Practice of Greek Exegesis. (Dallas: Dallas Theological Seminary, 1974), 6.

${ }^{4}$ John Grassmick. Principles and Practice of Greek Exegesis, 7; André Verweij. "The Personal Presence of the Preacher in Preaching: An Explorative Study on Self-Disclosure in Sermons at Pentecost." Homiletic: The Journal of the Academy of Homiletics, 45, no.2 (2020): 36-52. https://doi.org/10.15695/hmltc.v45i2.4999. eksegese ke dalam naskah kotbah. ${ }^{5}$ Eksegesis untuk sebuah kotbah tidak berbeda jenisnya dari apa yang diminta penulisan sebuah karya eksegesis, namun ia berbeda dalan tuntutan dan tujuannya. ${ }^{6}$ Kotbah sebagai tindakan ketaatan dan penyembahan, seharusnya tidak dibungkus oleh akademis yang buruk dalam jubah kesungguhan. Tugas eksegesis adalah menemukan Firman itu dan artinya dalam gereja abad pertama. Tugas berkotbah adalah untuk mengenal dengan baik eksegesis teks dan orang-orang yang kepadanya Friman itu sekarang mau disampaikan lagi, sebagai Firman hidup bagi mereka. Berkotbah harus didasarkan atas ekesgesis yang mumpuni, namun ia bukan peragaan eksegesis. Melainkan ia menerapkan ekesegesis, dan harus memiliki tujuan bila ingin berfungsi dengan baik. ${ }^{7}$ Eksegese untuk persiapan kotbah tidak dapat dan tidak perlu mendalam seperti untuk makalah. Fakta bahwa eksegese ini tidak mendalam tidak berarti itu tidak memadai. ${ }^{8}$ Hasil akhir, kotbah akan dan harus didasarkan pada riset yang ilmiah dan yang menghormati

\footnotetext{
${ }^{5}$ Douglas Stuart. Eksegese Perjanjian Lama. (Jawa Timur: Penerbit Gandum Mas, 2004), 96.

${ }^{6}$ Gordon D. Fee. (diterjemahkan Amdreas Hauw). Eksegesis Perjanjian Baru, III. (Malang:Literatur SAAT, 2008), 171.

7 Gordon D. Fee. Eksegesis Perjanjian Baru, III, 171-173. 97
} 
Allah. Kotbah sebagai wujud dari ketaatan dan penyembahan, tidak boleh menyelubungi ilmu pengetahuan yang bermutu rendah dalam semangat yang berlebih-lebihan. Jadikan kotbah yang menggairahkan, dengan tetap menjaga agar tidak menyimpang dari kebenaran Firman Tuhan.

\section{METODE}

Metode yang digunakan untuk menganalisa topik ini adalah metode hermeneutika. Pada awalnya hermeneutika selalu dikaitkan dengan teologi, karena hermeneutika adalah metode intepretasi Kitab Suci yang dapat melahirkan dogma. Tetapi secara tidak langsung teologi memengaruhi dan dipengaruhi filsafat, pada beberapa abad terdahulu tidak ada perbedaan dalam jenis filsafat-filsafat hermeneutika. Terminologi hermeneutik berkaitan erat dengan usaha mencari sebuah teori pengetahuan bagi kajian terhadap teks, tanda dan berbagai bentuk symbol, ritual, imaji, dan secara tradisional digambarkan sebagai seni menafsirkan bahasa. $^{9}$ Hermeneutika memiliki peran strategis dalam mendialogkan teks yang maknanya masih ambigu menjadi jelas dan tidak multitafsir,

${ }^{9}$ Roy J, Howard (ed. Ninuk Kleden Probonegoro). Pengantar Teori-teori Kontemporer Hermeneutika. Bandung: Nuansa Cendikia, 2019. merasionalisasikan pesan yang terkandung dalam teks agar lebih mudah dipahami, serta menafsirkan maksa suatu teks agar lebih komprhensif, holistic, dan mampu menemukan pola baru di balik teks tersebut. Insturmen dalam penelitian hermeneutika lebih mengarah pada human instrument. Peneliti dituntut dapat memainkan kekuatan intuitifnya dalam menentukan sampel dan penangkapan data yang diperlukan dalam penelitian. Penelitian hermeneutik pada dasarnya berinduk pada penelitian kualitatif. ${ }^{10}$ Ini berarti analisis data bersifat proses, yang menjadi bagian tak terpisahkan dalam proses penemuan makna itu sendiri. Proses ini membutuhkan dua hal, yaitu pengetahuan peneliti dan kekuatan logikanya.

\section{PEMBAHASAN}

Kotbah merupakan penyampaian pesan Allah kepada umat-Nya. Pesan tentang maksud dan kehendak Allah yang disampaikan melalui para hamba-Nya. Dari sini dapat dimengerti keterkaitan antara kotbah dan pengkotbah. Pengkotbah adalah orang yang menyampaikan pesan Allah kepada umat-Nya, sementara kotbah adalah materi atau pesan Allah yang

\footnotetext{
${ }^{10}$ Darmiyati Zuchdi, dan Wiwiek Afifah. Analisis Konten Etnografi dan Grounded Teori dan Hermeneutika dalam Penelitian. (Jakarta: Bumi Aksara, 2019), 241.
} 
disampaikan oleh pengkotbah tersebut. ${ }^{11}$ Kotbah bukanlah suatu risalah atau karangan sastra untuk diterbitkan dengan maksud dibaca berulang-ulang, melainkan suatu berita yang dimaksudkan untuk didengar dan mempunyai dampak langsung pada pendengarnya. $^{12}$ Karena pesan yang disampaikan itu adalah pesan Allah, maka seorang pengkotbah, ketika menyampaikan kotbahnya tidak akan pernah bisa melepaskan dirinya dari pimpinan dan penerangan Allah. Pimpinan dan penerangan Roh Kudus akan membuat Firman Allah yang disampaikan itu berkuasa untuk mengubah kehidupan orang percaya. ${ }^{13}$ Suatu kotbah terdiri dari banyak elemen. Elemen-elemen itu dapat diperhatikan sebagai berikut:

\section{Pendengar Kotbah}

Hal utama yang perlu diperhatikan dalam berkotbah adalah pendengar. Pendengar kotbha ini akan menjadi dasar dan tujuan kotbah. Perlu diperhatikan bahwa ada dua pendengar kotbah ketika suatu kotbah disampaikan, yang pertama

\footnotetext{
11 John Stott \& Greg Scharf, Tantangan dalam Berkotbah, (Jakarta: Yayasan Komunikasi Bina Kasih, 2013), 58-59.

12 James Braga. Cara Mempersiapkan Kotbah, (Jawa Timur: Gandum Mas, 2011), 77.

${ }^{13}$ Susanto Dwiraharjo. Tujuh Langkah dalam Berkotbah. (Jakarta: STT Baptis Jakarta, 2015), 34; Bobby Kurnia Putrawan. "Pengantar Teologi Pentakosta." QUAERENS: Journal of Theology and Christianity Studies, 1 no.1 (2019): 1-7. https://doi.org/10.46362/quaerens.v1i1.2.
}

dan terutaman adalah Tuhan sendiri, dan yang kedua adalah jemaat.

Pertama, seorang pengkotbah, tidak salah apabila memperhatikan jemaat sebagai pendengarnya. Tetapi pertanyaannya adalah apakah jemaat merupakan pendengar utama dari kotbanya. Jemaat memang menjadi pendengar, tetapi pada hakekatnya mereka bukanlah pendengar utama, pendengar utama kotbah kita bukanlah Allah sendiri? Tuhanlah pendengar kotbah utama kita, bukan orang-orang, oleh sebab itu seharusnyalah seorang pengkotbah memiliki motivasi untuk menyenangkan hati Allah di atas para pendengar. Apabila seorang pengkotbah melupakan atau mengabaikan kenyataan ini, ia akan jatuh ke dalam jebakan. Kotbah yang disampaikan bukan untuk kemuliaan atau menyenangkan Tuhan tetapi hanya untuk menyenangkan telinga pendengar, dan ini tentu sangat mendukakan hati Tuhan. Pengkotbah yang berkotbah bukan untuk menyenangkan hati Tuhan, tetapi untuk pendengar pada intinya ia bukanlah pengkotbah. 14 Dari satu sisi, fungsi pengkotbah sama dengan seorang nabi, dan pada titik ini mereka sedang menyuarakan suara Tuhan. Suara Tuhan harus disampaikan entah itu

\footnotetext{
14 Susanto Dwiraharjo. Tujuh Langkah dalam Berkotbah, 38-39.
} 
menyenangkan telinga pendengar atau tidak.

Kedua adalah jemaat. Jim Shadix dan Vines sebagaimana dikutip oleh Susanto Dwiraharjo, menerangkan bahwa Seorang pengkotbah perlu mengerti karakteristik para pendengar yang akan mendengarkan kotbahnya. Mengerti keberadaan pendengar akan menolong pengkotbah mengkotbahkan apa yang diperlukan oleh pendengar. Suatu kotbah ditujukan secara sengaja kepada pendengar atau jemaat yang tertentu. Kotbah perlu dipahami sebagai acara di mana Tuhan menyampaikan pesan-Nya berupa ajaran serta pengarahan-Nya yang mempengaruhi kehidupan manusia, dalam kaitannya dengan Kristus, dan berdasarkan Alkitab kepada sekelompok orang yang hadir melalui perkataan seseorang juru bicara. Kotbah disampaikan bukan sekedar penyampaian suatu informasi yang bersifat normatif, tanpa mempertimbangkan kondisi atau keberadaan dari pendengarnya. Suatu kebenaran yang sering terabaikan adalah fakta bahwa tidak ada dua kotbah pun yang disampaikan atau melibatkan pendengar yang sama. Meski jemaat minggu ini terdiri dari orang-orang yang sama seperti yang hadir minggu sebelumnya, namun pengalaman, sikap, serta emosi mereka berbeda. Oleh sebab itu seorang pengkotbah harus selalu mempertimbangkan pendengar macam apa yang akan hadir. Ini berarti setiap kali mempersiapkan kotbah ia harus mempelajari orang-orang yang akan mendengarkan beserta konteksnya. Berkotbah berarti menyampaikan pesan Tuhan kepada sekelompok orang tertentu, maka penyampaian kotbah sejati selalu mempertimbangkan sifat para pendengar dan suasananya. ${ }^{15}$ Suatu kebenaran yang sering terabaikan adalah fakta bahwa tidak ada dua kotbah pun yang disampaikan atau melibatkan pendengar yang sama. Meski jemaat minggu ini terdiri dari orang-orang yang sama seperti yang hadir minggu sebelumnya, namun pengalaman, sikap, serta emosi mereka berbeda. ${ }^{16}$ Oleh sebab itu seorang pengkotbah harus selalu mempertimbangkan pendengar macam apa yang akan hadir. Ini berarti setiap kali mempersiapkan kotbah ia harus mempelajari orang-orang yang akan mendengarkan beserta konteksnya. Berkotbah berarti menyampaikan pesan Tuhan kepada sekelompok orang tertentu, maka penyampaian kotbah sejati selalu mempertimbangkan sifat para pendengar dan suasananya.

15 Jerry Vines \& Jim Shaddix. Homiletika, Kuasa dalam Berkotbah, (Malang: Penerbit Gandum Mas, 2014), 34.

16 Jerry Vines \& Jim Shaddix. Homiletika, Kuasa dalam Berkotbah, 35. 


\section{Penggalian Kotbah}

Ada begitu banyak pola penggalian kotbah, dan dalam bahasan ini akan menggunakan metode penggalian eksegesis. Kotbah eksegesis memerlukan jalan atau cara untuk memahami teks. Seorang eksegetor tidak hanya mengikuti cara yang dapat menerangi pribadinya, tetapi juga harus belajar ketika terang itu juga digunakan untuk memberi terang yang lain. Ini merupakan media transformasi spiritual. ${ }^{17}$ Transformasi spiritual sangat tergantung pada perjumpaannya dengan kebenaran firman Tuhan. Tidak ada bagian gelap di dalam Alkitab bagi seorang pengkotbah. Semua itu sangat tergantung pada penggalian seorang pengkotbah terhadap teks yang akan disampaikan.

Dalam proses penggalian ini akan menggunakan prinsip-prinsip eksegesis. Secara umum proses eksegesis ini akan dibagi ke dalam delapan langkah utama. Ke delapan langkah berbeda satu dengan yang lain namun merupakan satu kesatuan yang mengarah pada sasaran utamanya. Langkah-langkah itu adalah:

\section{Teks Dan Terjemahan}

Dalam persiapan kotbah, hal paling utama bagi seorang pengkotbah adalah

17 Bryan Chapell, Christ-Centered Preaching, (Michigan: Baker Books, 2001), 99. memilih teks kotbah. Tujuan dari penyelidikan teks adalah untuk menentukan varian mana yang paling mungkin teks asli, dan bagian mana yang dinilai salah. ${ }^{18}$ Ini merupakan hal yang wajar bagi seorang pengkotbah. Tanpa hal ini, tentu kotbah itu tidak akan pernah terjadi. Bagi seorang pengkotbah memilih teks kotbah pada intinya bukanlah pekerjaan yang mudah. Hal itu dikaitkan dengan banyaknya aspek yang terkait di dalamnya. Teks yang dikotbahkan bukanlah teks yang terpisah dari berbagai aspek yang mengikutinya. Aspek mendasar yang melatarbelakangi pemilihan teks antara lain berkenaan dengan kepekaan pengkotbah terhadap kehendak Tuhan. Ini berbicara berkenaan dengan apa yang Tuhan "mau" terhadap umat-Nya. $^{19}$ Ini berarti seorang pengkotbah harus menentukan batas-batas perikop kotbahnya, dan setelah itu membaca secara berulang, dan perlu memperhatikan ayat sebelum dan sesudahnya.

Setelah menentukan perikop yang akan dieksegesis, sebelum dikotbahkan, seorang pengkotbah perlu membangdingkannya dengan berbagai terjemahan. Ini berarti menganalisis berbagai versi, dan setelah itu 80

18 Gordon Fee. Eksegesis Perjanjian Baru.

${ }^{19}$ Susanto. Tujuh Langkah. 51 
menyusun kembali ke dalam terjemahan sendiri. Perbandingan ini perlu karena masing-masing versi memiliki karakteristik yang berbeda, dan untuk menemukan kebenaran yang menyeluruh maka diperlukan pembandingan antara beberapa versi, dan juga perlu melihat ke dalam teks bahasa asli kitab ditulis. Dengan mencermati teks bahasa asli kitab ditulis, barangkali akan ditemukan berbagai persoalan teks yang perlu diselesaikan. Perhatikan secara khusus perbedaan yang benar-benar dapat memengaruhi arti teks itu bagi jemaat dalam terjemahan baru. ${ }^{20}$ Dengan membandingkan satu atau dua tafsiran teknis utama yang membahas masalah naskah dan terjemahan, ini dapat memeriksa apakah penentuan varianvarian utama itu sudah betul.

Langkah berikutnya yang perlu dilakukan oleh seorang pengkotbah adalah membuat terjemahan sendiri. Di sini, seorang eksegetor perlu membandingkan teks tersebut dengan beberapa versi terjemahan yang dinilai baik. Perbandingan teks ini diperlukan karena seringkali seorang penterjemah harus menentukan pilihan satu dari sekian banyak arti bahasa asli teks ditulis, bahasa Ibrani untuk Perjanjian

${ }^{20}$ Douglas. Eksegese Perjanjian Lama. 98.
Lama dan bahasa Yunani untuk Perjanjian Baru. $^{21}$ Seorang penafsir dapat menentukan versi-versi terjemahan mana yang akan dibandingkan. Sudah barangtentu pemilihan versi ini tidak ditentukan secara serampangan tetapi atas berbagai pertimbangan yang matang. Perlu memperhatikan jenis atau model terjemahan; apakah literal, kontekstual atau jenis lain, namun dibalik itu semuanya perlu menggunakan bahasa asli teks ditulis. Ini sebagai penentu akhir atas terjemahan yang akan dibuat.

Sebagai kesimpulan dari bagian ini, seorang pengkotbah perlu; 1) memperhatikan beberapa terjemahan Inggris/Indonesianya untuk melihat dimana perbedaan utama yang harus dijelaskan. 2) memerhatikan setiap kesulitan tekstual utama yang perlu diperhatikan lebih lanjut. 3) mendaftarkan kata-kata kunci yang perlu dipelajari kata-kata teologis yang membawa pesan dari bagian itu, katakata yang diulangi, atau kata-kata yang bermasalah. 3) meneliti perlengkapan puisi dan kiasan, dan tandai semua yang perlu dijelaskan dalam eksegesis. 4) memerhatikan setiap tata bahasa

${ }^{21}$ Gordon D. Fee and Douglas Stuart. How to Read the Bible for All Its Worth. (Zondervan: IMPrint, 2007), 33. 
yang tidak jelas atau sulit atau ekspresi sintaktikal yang perlu dipelajari dan dijelaskan. 5) menandai kata-kata kerja utama yang perlu dijelaskan berkaitan dengan waktu, mood atau bentuk tindakan. 6) memerhatikan setiap motif atau pola-pola yang dibentuk pada bagian sebelumnya. 7) mengenali setiap baris atau ayat yang dikutip atau merujuk baik Perjanjian Lama maupun Perjanjian Baru.

\section{Analisis Sejarah dan Sastra}

Kadang terjadi tumpang tindih antara konteks kesusastraan dengan sejarah, secara khusus dalam Perjanjian Lama. Namun sekalipun demikian, ada faedahnya untuk berusaha mengetahui apakah suatu bagian tersebut bersifat sastra atau sejarah. Hal pertama yang perlu dilakukan adalah berusaha untuk menentukan latar belakang kesusastraan yang umum dari teks yang akan diselidiki. Di sini seorang penafsir perlu mengetahui jenis sastranya, apakah itu berupa narasi, nubuatan, kiasan atau yang lainnya. Cara seperti ini juga digunakan untuk melihat latar belakang sejarah. Perhatikan latar belakang yang dekat, dan kemudian latar belakang secara keseluruhan. Pastikan bahwa jemaat mengerti apa yang terjadi sebelumnya, kejadian-kejadian yang berhubungan dengan pekerjaan Tuhan sebagai persiapan untuk teks yang akan diselidiki. 22 Bagian ini juga melihat berbagai peristiwa yang melatarbelakangi teks, dan juga peristiwa yang terjadi setelah teks. Pastikan jemaat mengerti tentang tempat, waktu, fungsi, pengarang, lingkungan social, letak geografis, kronologis dan juga arkeologi.

Hal yang perlu dilakukan setelah ini adalah latar depan dari bagian yang akan diselidiki. Ini berbicara tentang apa yang sedang terjadi setelah teks yang diselidiki, baik yang bersifat sejarah maupun sastra? Apa yang terjadi pada pasal-pasal berikutnya? Apakah hal itu berhubungan dan apakah dapat menambah pengertian tentang bagian Firman itu? Apakah yang terdapat sesudahnya? Adakah kejadian-kejadian yang terjadi segera sesudahnya itu memberi keterangan tentang teks yang diselidiki? ${ }^{23}$ Analisis ini sangatlah penting untuk dipahami karena; 1) hal itu dapat menolong penafsir dan juga jemaat mengerti latar belakang personal dari para tokoh Alkitab, 2) dapat mengerti latar belakang kitab dan tujuannya. Semuanya ini dapat menolong eksegetor dapat menemukan kebenaran yang sesungguhnya.

22 Douglas. Eksegese Perjanjian Lama, 101103.

23 Douglas. Eksegese Perjanjian Lama, 104. 


\section{Analisis Kontekstual}

Dalam analisis kontekstual ini ada empat jenis konteks yang perlu diperhatikan; konteks teks, konteks kitab, konteks kanon/Alkitab dan konteks antara. Masing-masing konteks memiliki fungsi sama yaitu menemukan kebenaran yang sebenarnya. Semuanya ini akan menolong eksegetor untuk menemukan arti sesuai dengan konteksnya. Ini berarti ada keterikatan erat antara konten dan konteks.

Ada beberapa konteks yang perlu diperhaikan; Pertama konteks teks. Sebuah pengulangan istilah, frase, klausa, atau kalimat sebagai "kepala" untuk memperkenalkan setiap bagian atau untuk menyimpulkan tindakan setiap seksi. Kadang kala ditandai dengan adanya datadata gramatikal atau kata keterangan, contoh: "kemudian, oleh karena itu, dimana saja, tetapi, sementara (dalam hermeneutik disebut: Hukum Struktur). Kadang berupa kalimat retorika, Perubahan waktu, tempat atau bahwa peristiwa. Suatu bentuk vokatif. Perubahan tensis, mood, atau aspek-aspek kata kerja yang lain. Pengulangan dari kata kunci yang sama, atau konsep yang menjadi batasan dari seksi/paragraf. Kedua, konteks kitab. Identifikasi tujuan buku. Perhatikan perubahan seksi ke seksi atau paragraf ke paragraph. Perhatikan juga beberapa hal ini: Temukan tujuan penulis di dalam pendahuluan, tubuh teks atau kesimpulan. Temukan bentuk-bentuk aplikasi penulis dari doktrinal ke praktikal. Susunlah temuan itu. Seorang penafsir harus bekerja sesuai dengan tujuan penulis. Ketiga kontek Kanon atau Alkitab. Analisis kontek berarti harus berfokus pada bentuk akhir teks itu sendiri. Setiap bagian dari teks dilihat bukan sebagai "bukti teks" tetapi harus dilihat konteks keseluruhan buku dan juga dalam keseluruhan kanon. Di sini seorang eksegetor harus dapat melihat ada tidaknya kesejajaran konteks teks itu ke kitab-kitab lain di seluruh Alkitab. Keempat konteks perantara. Dalam konteks ini seorang eksegetor perlu memperhatikan; 1) aspek historical. Ini berarti seorang eksegetor perlu memperhatikan hubungan beberapa fakta, peristiwa, atau kejadian-kejadian didalam suatu waktu, 2) teologikal, ini merupakan rumusan doktrin tergantung pada fakta historis yang ada dan keadaankeadaan, 3) logical, ini merupakan suatu paragraf yang berhubungan dengan sebuah argumen atau garis pemikiran yang berada di bawah keseluruhan seksi, 4) psikologikal, kadang-kadang dalam pendahuluan sudah muncul suatu ide, perhatikan bahwa seringkali itu akan mempengaruhi keseluruhan seksi. ${ }^{24}$ Semua

${ }^{24}$ Walter C. Kaiser. Toward an Exegetical Theology, 71- 84 
konteks ini akan menolong seorang eksegetor dapat menemukan kebenaran sesuai dengan maksud pertama penulis kepada jemaat pertama.

\section{Analisis Gramatikal dan Sintektikal}

Dalam analisa gramatikal dan sintaktikal ini yang perlu diperhatikan adalah kaidah dari tata bahasa tersebut dalam arti pada suatu kata. Di sini, seorang eksegetor akan melihat kaidah grammar pada suatu kata tersebut. Ini juga dilakukan dengan membandingkan berbagai versi Inggris/Indonesia untuk melihat dimana pembahasan terhadap teks harus dimulai. Sintak merupakan satu hal yang sangat penting di dalam menafsirkan satu bagian Firman Tuhan. Melalui ini seorang penafsir dapat merekontruksi arti sesuai dengan apa yang dimaksud oleh penulis. Ada beberapa dasar yang perlu diperhatikan; 1) Melihat fungsi gramatikal di dalam frase, klausa, atau kalimat, 2) Memperhatikan kata-kata, frase, kalusa, paragraf yang mengikatnya, 3) memperhatikan struktur kalimatnya (semantiknya). ${ }^{25}$

Di samping beberapa kebenaran di atas, perlu diperhatikan pula keterkaitan antara sintektikal dengan rumusan teologi; bagaimana peran sintektikal (gramatikal)

25 Walter C. Kaiser. Toward an Exegetical Theology, 87. di dalam merumuskan satu kebenaran teologi? Dan bagaimana peran sintektikal di dalam menemukan kebenaran sesuai apa yang dimaksud oleh penulis kitab. ${ }^{26}$ Secara teknis dalam grammar dan sintak ini, seorang penafsir perlu memperhatikan fungsi dari masing-masing bentuk sintak tersebut; 1) Kata benda, Pelajaran mengenai sebuah kata benda dalam suatu kalimat akan melibatkan pelajaran mengenai angka, gender, dan kasus. Garis besar ini akan berfokus pada kebutuhan yang paling sering, mengerti kasusnya, nominative, genitive, dan accusative. 2) Kata kerja, seorang penafsir perlu memperhatikan fungsi stem untuk PL atau tensis untuk PB. Masing-masing bentuk ini menjelaskan tentang makna kata dibalik fungsi grammar tersebut. 3) bentuk Volatif secara khusus dalam PL. Ini terdiri atas tiga hal utama yaitu jusif, imperatif dan kohortatif. Jussif adalah mood volitional dari orang ketiga, dan orang kedua saat dinegasikan (dengan al ditambah orang kedua kita mendapatkan suatu perintah negatif). Kekuatan dari jussif sangat beragam dari konteks ke konteks, dan terutama bergantung pada relasi pembaca dan subjek. Imperatif, adalah volitional mood dari orang kedua semata. Ini tidak pernah muncul dengan negative adverbs

\footnotetext{
${ }^{26}$ Walter C. Kaiser. Toward an Exegetical Theology, 89.
} 
(jussives dan imperfects digunakan untuk memberi perintah negatif dan larangan). Kekuatan perintah sangat beragam dalam kekuatannya dari konteks ke konteks, tapi selalu memiliki tekanan pada jawaban langsung. Terkadang eksegetor harus menggambarkan bentuk kekuatan jika tidak satupun kategori cocok. Kohortatif, adalah volitional mood dari orang pertama, tunggal atau jamak. Itu menunjukan kemauan pembicara dalam suatu ketetapan hati terhadap kehendak orang lain. 4) Bentuk verbal infinitif dan partisip. Suatu infinitive absolute adalah sebuah verbal noun. Itu bisa berfungsi dalam sebuah kalimat secara nominal atau verbal. Itu menggambarkan tindakan dari ide verbal dengan tidak melihat agen, keadaan, waktu atau mood dimana hal itu terjadi. Suatu infinitive construct juga merupakan suatu verbal noun, suatu infinitive sejati tanpa batasan waktu. Suatu infinitive construct lebih nominal daripada bentuk infinitive absolute. Tapi itu bisa digunakan secara substantivally (ditempat sebuah kata benda) atau secara verbal. Suatu active participle menyatakan aktifitas yang berkelanjutan tanpa terganggu, atau suatu kondisi berkelanjutan yang didenotasikan oleh kata kerja. Itu temporal, tergantung pada konteks waktunya. Seperti adjaktif itu bisa berfungsi seperti predikatif (verbally), attributive (adjectival), atau substantivally (sebagai sebuah kata benda). ${ }^{27}$

\section{Analisis Leksikal}

Penelitian kata dalam Alkitab sangat diperlukan untuk suatu eksegesis yang akurat dan penting bagi eksegesis yang kaya. Ada tiga wilayah yang akan dipelajari dalam proses ini yaitu, menelusuri penggunaan suatu kata, meneliti etimologinya, dan mensurvey penerjemahannya dalam versi-versi kuno. Sebagian besar buku mengenai hal ini akan memberikan etimologinya terlebih dahulu, dan kemudian berurusan dengan penggunaan serta versinya. Pelajaran mengenai etimologi adalah yang paling sulit, tapi karena itu diperlukan untuk mempelajari kata-kata yang jarang dan bermasalah dalam Alkitab, hal ini tidak bisa dihindari. Pelajaran mengenai bagaimana sebuah kata digunakan lebih mudah, dan ini mengenai bagaimana melihat dari kata-kata teologi umum. ${ }^{28}$ Pelajaran mengenai bagaimana suatu kata diterjemahkan kedalam berbagai versi kuno (dan versi modern) juga lebih mudah karena hal ini berkaitan dengan bahasa,

${ }^{27}$ Scott M. Gibson. "The Urgency of Preaching in Challenging Times." Journal of the Evangelical Homiletics Society, 20, no.2 (2020): 2-4. https://journal.ehomiletics.org/index.php/jehs/ article/ view/145; Allen Ross. www. bible org. ${ }^{28}$ Allen Ross. www. bible org. 
dan sudah banyak buku tafsiran menggunakannya.

Dalam analisa leksikal ini, seorang penafsir akan memilih kata mana yang dinilai penting. Sudah barangtentu ini sangat subyektif. Namun sekalipun demikian, ada indicator yang dapat dijadikan rujukan untuk menentukan kata mana yang penting. Pertama adalah kata itu paling banyak muncul dalam paragraf tersebut, namun juga dapat dilihat, barangkali kata itu hanya muncul sekali namun mengikat arti semuanya. Hal ini dapat dilakukan dengan memilih secara bebas, tanpa rasa takut untuk menentukan dan mencatat kata yang dinilai menjadi kata kunci dalam paragraph tersebut. Berapa banyak istilah yang dapat didiskusikan dan kata mana yang dipilih sangat tergantung pada teks yang diselidiki. Seorang penafsir harus berusaha memilih secara relative sedikit saja untuk analisis secara terinci. ${ }^{29}$ Perlu dipahami pula bahwa setiap terjemahan barangkali akan menggunakan kata yang berbeda. Oleh karena itu disarankan untuk melihat ke dalam bahasa asli teks ditulis.

Setelah para penafsir menentukan kata mana yang dinilai penting, atau menjadi kata kunci pada teks atau paragraf tersebut, mereka akan menggali arti dari 85.

\footnotetext{
${ }^{29}$ Douglas. Eksegese Perjanjian Lama, 82-
}

kata tersebut. Penelusuran arti kata dapat diselidiki secara etimologi. Hal ini dilatarbelakangi kadang suatu kata akan memiliki arti yang berbeda ketika digunakan pada bagian lain dari teks Alkitab. Sehingga penelusuran secara etimologis sangat diperlukan, karena dapat memberi gambaran tentang arti yang sesuai teks.

\section{Analisis Teologi}

Tugas dari teolog Alkitab adalah mendapat dan membangun suatu gambaran lengkap mengenai wahyu Tuhan. Menulis teologi yang memuaskan menuntut pengelompokan ide teologis tertentu yang didapat melalui eksegesis kedalam kategori universal. Prosesnya melibatkan penemuan tema pemersatu diseluruh Perjanjian Lama dan meletakan dasar bagi Perjanjian Baru. Itu merupakan proses yang dimulai dengan eksegesis bagian tertentu dalam mencari kategori teologis dari penulis itu sendiri dan berlanjut dengan menghubungkan seluruh penemuan eksegesis diseluruh Alkitab. ${ }^{30}$ Maka dari itu, apa yang dilakukan dalam sebuah bagian atau satu kitab hanyalah sebuah permulaan.

Pada bagian ini, seorang penasir berusaha menemukan sumbangan teologi dari teks yang diselidiki. Berusaaha

\footnotetext{
${ }^{30}$ Allen Ross, www. bible org.
} 
menyelidiki teologi Alkitabiah dari bagian itu, dan meneliti apa yang dikatakan bagian itu tentang Tuhan, namaNya, natur-Nya, tindakan-Nya, dan apa yang dikatakannya tentang manusia, nama mereka, nature, tindakan, dan tentang perjanjian. Setelah itu memformulasikan temuan itu dalam suatu pernyataan teologis, sebagai sebuah prinsip teologi yang diajarkan bagian ini. ${ }^{31}$ Hubungkan pemikiran teologis, dan setiap maksud sampingan, dengan teologi Alkitab secara keseluruhan, baik Perjanjian Lama maupun Perjanjian Baru. Beberapa hal yang perlu diperhatikan antara lain; 1) Pastikan engingat bagaimana Perjanjian Baru menggunakan Perjanjian Lama. 2) Jika maksud teologis dari bagian itu tidak secara langsung dikutip oleh Perjanjian Baru, temukan tempat di mana teologi yang sama dicatat, 3) Hati-hati agar tidak membaca pemikiran PB ke dalam PL. ${ }^{32}$ Ini berarti yang pertama adalah menemukan formulasi teologinya, dan kemudian berusaha menemukan hubungannya dengan Perjanjian Baru.

Secara teknis, pada bagian ini para penafsir harus bisa menemukan formulasi teologi dari teks yang diseldiki. Setelah ini, mereka juga dapat menentukan

\footnotetext{
31 Walter Kaiser. Toward an Exegetical Theology, 131.

${ }^{32}$ Walter Kaiser. Toward an Exegetical Theology, 133.
}

masalah khusus yang ditimbulkan atau yang dipecahkan oleh bagian yang sedang diselidiki, secara utama perlu memperhatikan hal-hal yang bersifat khusus, dan bukan yang bersifat umum. Bagian akhir dari ini adalah memeriksa ulang sumbangan atau rumusan teolgis dari teks yang diselidiki.

\section{Analisis Homiletika}

Analisis homiletika ini diawali dengan suatu sintesis. Sintesis dari sebuah bagian dimulai dengan sebuah garis besar eksegetikal dan membentuk sebuah ringkasan eksegetikal. Dalam melakukan sintesis sebuah bagian perlu mengartikulasikan struktur dan kesatuan teks. Sebuah garis besar eksegetikal adalah sebuah garis besar yang menggambarkan di dalam kata-kata sendiri isi dari bagian itu. ${ }^{33}$ Hal ini ditulis dalam kalimat dan pikiran lengkap, serta bukan suatu topik. Hal itu harus berupa histories dan deskriptif dalam pengkalimatannya, ditafsirkan dan tidak mengambil kiasan tinggi.

Secara struktural hal itu dapat dijabarkan sebagai berikut; pertama, ringkas ayat atau klausa dalam narasi. Tulis sebuah pernyataan ringkasan secara singkat disetiap baris (biasanya setiap ayat

\footnotetext{
${ }^{33}$ Allen Ros. www. bible org.
} 
bahasa Inggrisnya). Jangan mengambil

bahasa kiasan dalam pengkalimatan kecuali itu sebuah idiom umum, tapi berikan suatu arti tafsiran jika mungkin. Jangan menyatakan kembali jika sudah dilakukan paralelnya, tapi tafsirkan seluruh ayat sebagai satu unit. Kedua, kelompokan ringkasan. Pelajari baris ringkasan untuk melihat mana yang bisa dikelompokan kedalam unit alami, apakah melalui bentuk struktur tulisan, atau melalui subjek masalah. Ketiga, ringkas tiap kelompok ringkasan. Setelah menetapkan pembagiannya, tulis ringkasan masingmasing. Ringkasan ini harus memasukan isi dari ayat-ayat dibawahnya, tapi tidak sedetil ringkasan individualnya. Kelompok ringkasan ini sekarang menjadi ringkasan sub-seksi lain, dan dibawahnya menjadi sub-points. Keempat, adalah ringkasan eksegetikal atau sintesis. ${ }^{34}$ Ini berarti menulis satu kalimat ringkasan dari keseluruhan bagian. Ini dilakukan untuk bisa melihat kesatuan dan organisasi dari suatu teks.

\section{Penerapan}

Ini langkah pendek untuk menemukan arti teks dan menentukan artinya bagi jemaat dimasa kini, tapi ini adalah langkah yang seringkali terlewatkan. Salah satu bagian terlemah

\footnotetext{
${ }^{34}$ Allen Ross. www. bible org.
}

dari eksegesis modern adalah penerapannya. Apakah ada penerapan penting, atau yang diberikan tidak berasal dari teks. Pembicara mungkin tidak tahu bagaimana mengembangkan sebuah penerapan, atau beranggapan ini sudah terbukti dengan sendirinya jika pesannya mendasar (cleverness is in, clarity is out), atau pembicara memiliki tujuan tanpa melihat teks apa yang digunakan. Sebuah eksegesis yang baik harus memasukan penerapan tertentu bagi pendengarnya. ${ }^{35}$ Pengkotbah harus menyatakan dengan jelas apa yang diinginkan untuk diketahui pendengar sebagai hasil eksegesis, apa yang diinginkan untuk dilakukan oleh jemaat. Penerapan harus jelas dan positif.

Ramesh Richard, sebagaimana dikutip oleh Susanto Dwiraharjo menyatakan bahwa di dalam kotbah eksegesis, aplikasi merupakan satu bagian tak terpisahkan dengan bagian-bagian yang lain. Eksegesis Alktiab tanpa aplikasi tidak akan berguna. Tidak ada poin akademik yang akurat jika informasi tidak ditransformasikan ke pendengar. Aplikasi adalah ketika seorang pengkotbah membawa pendengar dari sekedar menerima pewahyuan ke dalam dorongan implementasi kebenaran Firman Tuhan. Ketepatan aplikasi harus disesuaikan dan

\footnotetext{
${ }^{35}$ Allen Ross. www. bible org.
} 
dibuat konkret dengan pendengar. Di dalam menyesuaikan dan membuat konkret, perlu melihat korelasi homiletika atau hubungan antara sentral proposisi teks dan pendengar. ${ }^{36}$ Ini merupakan hubungan teologi dan spiritual. Ada hubungan teologi dan spiritual yang dapat menghubungkan pendengar dengan sentral proposisi teks.

\section{Penyampaian Kotbah}

Kerja eksegesis akan lebih berdaya guna apabila disampaikan dalam kotbah. Dalam penyampaikan kotbah, hal utama yang perlu dilakukan oleh seorang pengkotbah adalah internalisasi kebenaran Firman di dalam diri pengkotbah. Internalisasi berarti suatu proses pengendapan kotbah. Hal ini harus dilakukan oleh seorang pengkotbah. Sebelum menyampaikan kotbah, seorang pengkotbah perlu mengendapkan materi kotbahnya ke dalam dirinya. Ini juga merupakan proses penyatuan kotbah dengan seorang pengkotbah. ${ }^{37}$ Pada prinsipnya proses ini sudah dimulai sejak ia mempersiapkan kotbah sejak dari awal. Secara lebih khusus, proses ini mulai lebih terlihat ketika seorang pengkotbah mulai menulis naskah kotbahnya. Namun lebih

\footnotetext{
36 Susanto, Tujuh Langkah, 247.

37 Ramesh Richard, Scripture Sculpture. (Michigan: Baker Books, 1997), 142.
}

dari pada itu, seorang pengkotbah perlu mengambil waktu khusus untuk mengendapkan kotbahnya tersebut.

Dalam bukunya "Cara Berkotbah yang Baik" Haddon W. Robinson menyampaikan hasil suatu riset yang mencoba menghubungkan keterkaitan antara pengkotbah dan kotbahnya. Dari riset itu diketahui, pertama bahasa non verbal memiliki peran yang strategis dalam komunikasi di depan umum. Ketika seorang pengkotbah menyapa jemaat, ada tiga jaringan komunikasi yang berbeda yang berjalan pada waktu yang bersamaan; kata-kata, intonasi dan gerak tubuh. Ketiganya mengkomunikasikan ide-ide. Kedua, jika pesan non verbal berlawanan dengan yang verbal, maka pendengar mungkin akan lebih percaya bahasa yang tanpa kata tersebut. Nampaknya lebih sulit untuk berdusta dengan seluruh tubuh daripada hanya dengan bibir. Suatu kotbah tidak dapat dipisahkan dari sikap, baik yang menguatkan maupun yang mempertentangkan kata-kata apa yang dinyatakan. Seorang pengkotbah harus berani menyatakan pentingnya penyampaian. Ketiga, penyampaian yang efektif diawali dengan hasrat. Seorang pengkotah harus memiliki hasrat yang kuat untuk berkomunikasi di hadapan jemaat atau pendengar, dan bukan sekedar ingin menyampaikan ide-ide atau gagasan saja, 
namun berusaha agar ide-ide itu dapat ditransfer ke pendengar. Ada keingingan yang besar agar jemaat memahami apa yang disampaikan pengkotbah. ${ }^{38}$ Hal ini yang seharusnya menjadi hasrat bagi seorang pengkotbah. Penyampaian kotbah yang efektif paling tidak seperti percakapan sehari-hari yang saling memberi dan menerima.

Dalam penyampaian kotbah, seorang pengkotbah perlu memperhatikan gaya bahasa dan komunikasi nonverbalnya. Kedua bentuk komunikasi ini akan terlihat dan menjadi ciri utama bagi pengkotbah tersebut. Seorang pengkotbah perlu mengembangkan kedua-duanya. Oleh karena itu, seorang pengkotbah tidak hanya menghabiskan waktu untuk mempersiapkan materi, tetapi ia juga perlu mempersiapkan komunikasi penyampaiannya secara khusus di masa pandemi covid 19. ${ }^{39}$ Penggunaan komunikasi dengan baik akan mempermudah jemaat memahami atau menerima kotbah yang dipesankan.

${ }^{38}$ Haddon W. Robison, Cara Berkotbah yang Baik. (Yogyakarta:Yayasan Andi, 1980), 276-277; lihat Scott M. Gibson. "The Urgency of Preaching in Challenging Times", 2-4.

${ }^{39}$ André Verweij. "The Personal Presence of the Preacher in Preaching", 36-52; Susanto. Tujuh Langkah, 267; Matthew D. Kim. "Preaching in a Period of Pandemic and Prejudice." Journal of the Evangelical Homiletics Society, 20, no.2 (2020): 15-23. https://journal.ehomiletics.org/index.php/ jehs/article/view/147.

\section{KESIMPULAN}

Eksegesis kotbah merupakan pola kotbah yang penggalian teksnya menggunakan kaidah-kaidah eksegesis. Ini berarti seorang pengkotbah, dalam persiapan kotbahnya, menggali kebenaran dari suatu teks dengan berbagai analisis eksegetikal. Penggalian teks dengan berbagai bentuk analisi eksegesis ini merupakan upaya untuk menemukan arti asli ayat. Namun, ini pun tidak cukup, karena apa artinya sebuah galian eksegesis tanpa upaya membawa kebenaran tersebut ke dalam hidup orang percaya pada masa kini. Kebenaran Firman Tuhan yang ditemukan melalui kerja eksegesis itu akan disampaikan kepada umat itu dengan media kotbah. Kotbah merupakan media penyampaian kebenaran Firman Tuhan yang efektif, sebab di dalamnya menggunakan berbagai bentuk komunikasi.

\section{KEPUSTAKAAN}

Braga, James. Cara Mempersiapkan Kotbah. Jawa Timur: Gandum Mas, 2011.

Chapell, Bryan, Christ-Centered Preaching, Michigan: Baker Books, 2001.

Dwiraharjo, Susanto. Tujuh Langkah dalam Berkotbah. Jakarta: STT Baptis Jakarta, 2015. 
Fee, Gordon D. (diterjemahkan Andreas Hauw). Eksegesis Perjanjian Baru, III. Malang:Literatur SAAT, 2008.

Gibson, Scott M. "The Urgency of Preaching in Challenging Times." Journal of the Evangelical Homiletics Society, 20, no.2 (2020): 2-4. https://journal.ehomiletics.org/index.p $\mathrm{hp} /$ jehs/article/view/145

Grassmick, John. Principles and Practice of Greek Exegesis. Dallas: Dallas Theological Seminary, 1974.

Kaiser, Walter C., JR. Toward an Exegetical Theology, biblical Exegesis for Preaching and teaching. Grand Rapids: Baker Book House, 1988.

Kim, Matthew D. "Preaching in a Period of Pandemic and Prejudice." Journal of the Evangelical Homiletics Society, 20, no. 2 (2020): 15-23. https://journal.ehomiletics.org/index.p hp/jehs/article/view/147

Putrawan, Bobby Kurnia. "Pengantar Teologi Pentakosta." QUAERENS: Journal of Theology and Christianity Studies, 1 no.1 (2019): 1-7. https://doi.org/10.46362/quaerens.v1i 1.2 .

Richard, Ramesh. Scripture Sculpture. Michigan: Baker Books, 1997.
Robison, Haddon W. Cara Berkotbah yang Baik. Yogyakarta: Yayasan Andi, 1980.

Software Alkitab. www. bible org.

Stuart, Douglas. Eksegese Perjanjian Lama. Jawa Timur: Penerbit Gandum Mas, 2004.

Stott, John \& Greg Scharf, Tantangan dalam Berkotbah. Jakarta: Yayasan Komunikasi Bina Kasih, 2013.

Tadjibayev, Musajon. "Understanding a Deep Essence of a Literary Work without Comments." European Journal of Research and Reflection in Educational Sciences, 8, no.5 (2020), Part II: 26-31. https://www.idpublications.org/wpcontent/uploads/2020/05/FullPaper-UNDERSTANDING-ADEEP-ESSENCE-OF-ALITERARY-WORK-WITHOUTCOMMENTS.pdf

Verweij, André. "The Personal Presence of the Preacher in Preaching: An Explorative Study on SelfDisclosure in Sermons at Pentecost." Homiletic: The Journal of the Academy of Homiletics, 45, no. 2 (2020): $36-52$. https://doi.org/10.15695/hmltc.v45i 2.4999 . 
Vines, Jerry \& Jim Shaddix, Homiletika,

Penerbit Gandum Mas, 2014.

Kuasa dalam Berkotbah. Malang: 